WSRC-TR-2004-00342

\title{
Dissolution of Plutonium Metal Using a HAN Process
}

Mark L. Crowder and Tracy S. Rudisill

June 2004 
This document was prepared in conjunction with work accomplished under Contract No. DE-AC09-96SR18500 with the U. S. Department of Energy.

\section{DISCLAIMER}

This report was prepared as an account of work sponsored by an agency of the United States Government. Neither the United States Government nor any agency thereof, nor any of their employees, makes any warranty, express or implied, or assumes any legal liability or responsibility for the accuracy, completeness, or usefulness of any information, apparatus, product or process disclosed, or represents that its use would not infringe privately owned rights. Reference herein to any specific commercial product, process or service by trade name, trademark, manufacturer, or otherwise does not necessarily constitute or imply its endorsement, recommendation, or favoring by the United States Government or any agency thereof. The views and opinions of authors expressed herein do not necessarily state or reflect those of the United States Government or any agency thereof.

This report has been reproduced directly from the best available copy.

Available for sale to the public, in paper, from: U.S. Department of Commerce, National Technical Information Service, 5285 Port Royal Road, Springfield, VA 22161, phone: (800) 553-6847, fax: (703) 605-6900

email: orders@ntis.fedworld.gov

online ordering: http://www.ntis.gov/help/index.asp

Available electronically at http://www.osti.gov/bridge

Available for a processing fee to U.S. Department of Energy and its contractors, in paper, from: U.S. Department of Energy, Office of Scientific and Technical Information, P.O. Box 62, Oak Ridge, TN 37831-0062,

phone: (865)576-8401,

fax: (865)576-5728

email: $\underline{\text { reports@ adonis.osti.gov }}$ 
This page was intentionally left blank 
WSRC-TR-2004-00342

\section{Summary}

Thermal stability tests were conducted with a nitric acid $\left(\mathrm{HNO}_{3}\right)$ / hydroxylammonium nitrate (HAN) / potassium fluoride (KF) solution. The solution has great potential for use in plutonium dissolution because of the small quantity of hydrogen and other offgases produced. Tests were carried out in a Reactive Systems Screening Tool (RSST). The RSST is a calorimeter equipped with temperature and pressure probes as well as a heater that can heat a liquid sample at a programmed rate. In most cases, the calorimeter was pressurized with nitrogen to reduce evaporation of the liquid sample during heating.

For the proposed solution, $2 \mathrm{M} \mathrm{HNO}_{3} / 0.6 \mathrm{M} \mathrm{HAN} / 0.1 \mathrm{M} \mathrm{KF}$, an autocatalytic reaction occurred between 113 and $131^{\circ} \mathrm{C}$ with 300 psig or 50 psig nitrogen inside the RSST vapor space. At ambient pressure, the solution boiled at about $110^{\circ} \mathrm{C}$. After extensive boiling, the concentrations of $\mathrm{HNO}_{3}$ and HAN increased and the autocatalytic reaction occurred. Tests were also conducted with 1000 ppm Fe present in the $\mathrm{HNO}_{3} / \mathrm{HAN} / \mathrm{KF}$ solution. The range of the autocatalytic reaction initiation temperature was reduced to $105-120.5^{\circ} \mathrm{C}$. With iron at ambient pressure, boiling still occurred above $100^{\circ} \mathrm{C}$ prior to the autocatalytic reaction, which occurred at $108-109^{\circ} \mathrm{C}$. These results demonstrated the stability of the proposed HAN flowsheet, for which the planned dissolving temperature is $50-60^{\circ} \mathrm{C}$.

Additional tests were carried out with more concentrated solutions to further characterize the autocatalytic reaction initiation temperature. Increasing the nitric acid concentration to $3 \mathrm{M}$ decreased the reaction initiation temperature to $102-103^{\circ} \mathrm{C}$. Increasing the HAN concentration increased the temperature rise of the reaction from $10-30^{\circ} \mathrm{C}$ to $>40^{\circ} \mathrm{C}$. Increasing both reactants to $3 \mathrm{M}$ nitric acid and $0.9 \mathrm{M}$ HAN - yielded a reaction initiation temperature of $91^{\circ} \mathrm{C}$ (with or without iron), the lowest observed in this study.

This study was the first part of a larger flowsheet development / demonstration program for the plutonium metal dissolving process. The results of the study may be useful for similar flowsheets.

\section{Background}

Much of the excess plutonium from reduction in the nuclear weapons stockpile is still in the form of pits. Before this material can be dispositioned in a mixed oxide fuel, the pits must be disassembled and impurities potentially harmful to the fuel removed. Dissolution of the $\mathrm{Pu}$ metal following pit disassembly facilitates the required purification. Pu metal dissolutions have been performed in SRS facilities using both sulfamic acid and nitric acid/fluoride flowsheets. Since that time, the maximum allowable concentration of hydrogen in offgas from the dissolution process has been reduced to 1 volume percent to meet NFPA requirements. The concentration of hydrogen in the offgas from both demonstrated flowsheets will exceed this value unless large volumes of air are used for dilution. In response to this problem, the feasibility of using a nitric acid $\left(\mathrm{HNO}_{3}\right)$ / hydroxylammonium nitrate (HAN) / fluoride flowsheet was demonstrated by D.G. Karraker ${ }^{1}$. This flowsheet generated $10-15 \%$ of the gas evolved from the sulfamic acid process and a very small quantity of hydrogen; however, the small scale of the experiments did not allow for precise quantification of the hydrogen produced. Other advantages 
of the $\mathrm{HNO}_{3}$ / HAN / KF flowsheet are that dissolving residues are not pyrophoric and dissolving rates higher than a sulfamic acid flowsheet are readily attainable.

Historically, HAN has been used as a reductant in the PUREX and other plutonium processing operations. The reaction is given as

$$
2 \mathrm{NH}_{3} \mathrm{OH}^{+}+4 \mathrm{Pu}^{+4} \rightarrow 4 \mathrm{Pu}^{+3}+\mathrm{N}_{2} \mathrm{O}+\mathrm{H}_{2} \mathrm{O}+6 \mathrm{H}^{+}
$$

Incidents at Hanford, the Savannah River Site, and elsewhere ${ }^{2}$ have focused attention on the safe use of hydroxylamine (HAN) and its compounds. Early work on the oxidation of HAN by $\mathrm{HNO}_{3}$ demonstrated that "reaction is only observed at sufficiently high nitric acid concentrations; at $25 \mathrm{C}$ the cut-off is about $2.5 \mathrm{M} \mathrm{HNO}_{3} . " 3$ After an induction period, the reaction is rapid and autocatalytic, producing heat very quickly. The reactions involved are

$$
\begin{gathered}
4 \mathrm{NH}_{3} \mathrm{OH}^{+}+2 \mathrm{HNO}_{3} \rightarrow 3 \mathrm{~N}_{2} \mathrm{O}+3 \mathrm{H}_{2} \mathrm{O}+4 \mathrm{H}^{+} \\
\mathrm{NH}_{3} \mathrm{OH}^{+}+2 \mathrm{HNO}_{3} \rightarrow 3 \mathrm{HNO}_{2}+\mathrm{H}_{2} \mathrm{O}+\mathrm{H}^{+} \\
3 \mathrm{HNO}_{2} \rightarrow \mathrm{HNO}_{3}+2 \mathrm{NO}+\mathrm{H}_{2} \mathrm{O} \\
2 \mathrm{NO}+\mathrm{O}_{2} \rightarrow 2 \mathrm{NO}_{2}
\end{gathered}
$$

In the first task of the Pu metal dissolving program, the thermal stability of the $2 \mathrm{M} \mathrm{HNO}_{3} / 0.6 \mathrm{M}$ HAN / 0.1M KF solution proposed for the process was demonstrated.

\section{Experimental}

All tests were conducted in a Reactive Systems Screening Tool (RSST) from Fauske and Associates, Inc. The RSST is a nearly adiabatic calorimeter equipped to heat samples at a programmed rate and to record sample temperature and pressure at specified intervals. With the RSST, a sealed 350-mL Parr bomb houses an uncovered sample in a small, thin round-bottomed flask. The flask is surrounded by a small resistance heater and insulation before being loaded into the calorimeter. A thermocouple is placed in contact with the sample solution. For most tests in this study, the RSST vessel was pressurized with nitrogen gas to minimize vaporization of reactive components. Samples were nominally $11 \mathrm{~g}(10 \mathrm{~mL})$ and a small magnetic stir bar was used. The experimental set-up is shown in Figure 1. In this study, the programmed heating rate was $1^{\circ} \mathrm{C} / \mathrm{min}$ and temperature and pressure were typically recorded every $1^{\circ} \mathrm{C}$. 
WSRC-TR-2004-00342

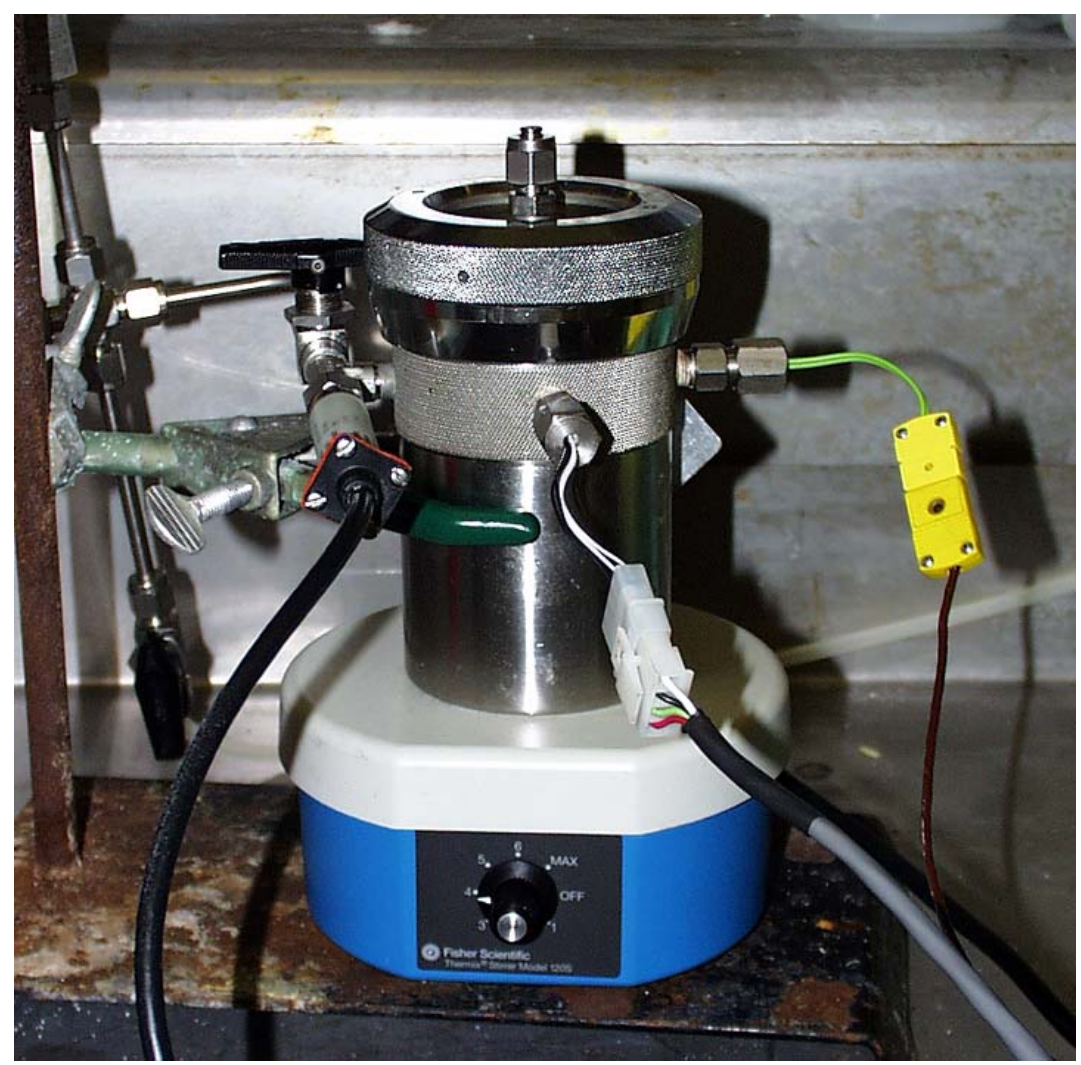

Figure 1. Reactive Systems Screening Tool (RSST) during Testing.

Test solutions were made from reagent grade nitric acid, a commercial grade 1.8M HAN stock solution, and distilled water. Potassium fluoride was added as anhydrous, but iron was added in the form of ferric nitrate nonahydrate: $\mathrm{Fe}\left(\mathrm{NO}_{3}\right)_{3} \bullet 9 \mathrm{H}_{2} \mathrm{O}$. Solution batches were $75 \mathrm{~mL}$, providing enough material for about 6 RSST tests per batch.

\section{Results}

Typical temperature versus time plots for the dissolver solution used in this study are shown in Figure 2. Notice that for the typical solution pressurized at 300 psig with nitrogen, the temperature of the solution increases at the programmed rate until the reaction occurs almost instantaneously. In contrast, the typical solution at ambient pressure reaches a temperature plateau where vaporization begins and the solution is concentrated. The reaction occurs almost instantaneously, but the magnitude is lower. For the more concentrated solution, the reaction begins at a lower temperature, as expected. 


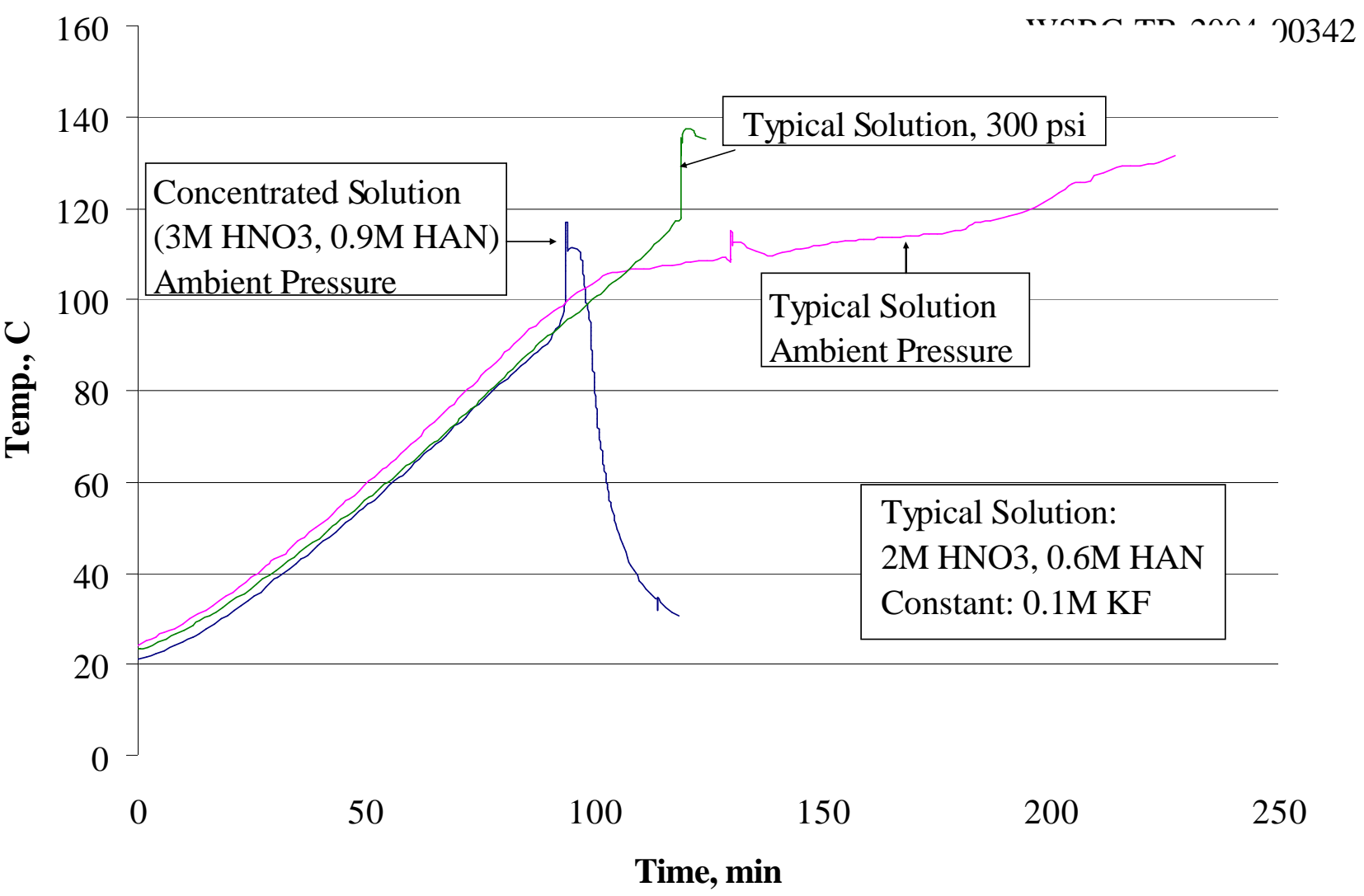

Figure 2. Characteristic reaction curves for dissolver solutions at different conditions.

Reaction characteristics for various solutions are provided in Tables 1-3. For the proposed dissolver solution, $2 \mathrm{M} \mathrm{HNO}_{3} / 0.6 \mathrm{M} \mathrm{HAN} / 0.1 \mathrm{M} \mathrm{KF}$, an autocatalytic reaction occurs between 113 and $131^{\circ} \mathrm{C}$ inside the RSST with either 300 psig or 50 psig nitrogen in the vapor space. Decreasing the RSST pressure from 300 to 50 psig did not seem to affect reaction temperature. However, when the RSST was operated at ambient pressure, the $\mathrm{HNO}_{3} / \mathrm{HAN} / \mathrm{KF}$ solution boiled at about $110^{\circ} \mathrm{C}$. After extensive boiling, the concentrations of $\mathrm{HNO}_{3}$ and $\mathrm{HAN}$ increased and an autocatalytic reaction occurred. These results bode well for the proposed HAN flowsheet, for which the planned temperature is $50-60^{\circ} \mathrm{C}$.

When the concentration of the nitric acid in the dissolver solution was increased, the autocatalytic reaction temperature decreased, as expected. A reference point in the literature ${ }^{2}$ gives an autocatalytic reaction temperature of $90^{\circ} \mathrm{C}$ for $3.0 \mathrm{M} \mathrm{HNO}_{3}$ and $0.5 \mathrm{M} \mathrm{HAN}$. The reaction temperatures observed in this study are about $10^{\circ} \mathrm{C}$ higher for $3.0 \mathrm{M} \mathrm{HNO}_{3} / 0.6 \mathrm{M} \mathrm{HAN}$

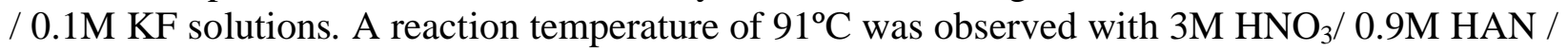
$0.1 \mathrm{M} \mathrm{KF}$, with and without $1000 \mathrm{ppm}$ of iron. For 2-3 $\mathrm{M} \mathrm{HNO}_{3}$, increasing the HAN concentration from 0.6 to $0.9 \mathrm{M}$ increased the observed temperature rise of the reaction from nominally $10-30^{\circ} \mathrm{C}$ to $>40^{\circ} \mathrm{C}$ for pressurized reactions. 
WSRC-TR-2004-00342

Table 1. Reaction Characteristics of Dissolver Solutions Pressurized with Nitrogen

\begin{tabular}{|c|c|c|c|c|c|c|c|}
\hline $\mathrm{HNO}_{3}$ & $\mathrm{HAN}$ & Po & $\operatorname{Trxn}$ & $\Delta \mathrm{T}$ & $\Delta \mathrm{P}$ & $\Delta \mathrm{t}$ & Comments \\
\hline $\mathrm{M}$ & $\mathrm{M}$ & $\mathrm{psig}$ & ${ }^{\circ} \mathrm{C}$ & ${ }^{\circ} \mathrm{C}$ & $\mathrm{psi}$ & $\mathrm{sec}$ & \\
\hline & & & & & & & \\
\hline 1.99 & 0.6 & 300 & 125 & 26 & 9.7 & 0.55 & \\
\hline 2 & 0.6 & 300 & 131 & 23 & 14 & 0.88 & Stirrer off until 124${ }^{\circ} \mathrm{C}$ \\
\hline 2 & 0.6 & 50 & 113 & 23 & 14 & 1.15 & Stirrer off \\
\hline & & & & & & & \\
\hline 2.02 & 0.6 & 300 & 128 & 23 & 7 & 0.6 & \\
\hline 2 & 0.6 & 300 & 122 & 26 & 9 & 0.99 & \\
\hline 2.03 & 0.6 & 300 & 114 & 27 & 6 & 1.15 & \\
\hline 2 & 0.6 & 300 & 119 & 27 & 8 & 1.65 & \\
\hline 2 & 0.6 & 300 & 118 & 27 & 8.5 & 0.94 & $0.2 \mathrm{M}$ Fluoride* \\
\hline & & & & & & & \\
\hline 3 & 0.6 & 300 & 103 & 29 & 5.7 & 0.71 & \\
\hline 3 & 0.6 & 300 & 102 & 27 & 5.5 & 0.6 & \\
\hline & & & & & & & \\
\hline 2 & 0.9 & 300 & 123 & 40 & 22 & 0.71 & \\
\hline 2 & 0.9 & 300 & 110 & 42 & 19 & 0.94 & \\
\hline & & & & & & & \\
\hline 2.5 & 0.75 & 300 & 118 & 33 & 13 & 0.72 & \\
\hline 2.5 & 0.9 & 300 & 102 & 40 & 18 & 0.93 & \\
\hline 3 & 0.9 & 300 & 91 & 44 & 12 & 0.93 & \\
\hline
\end{tabular}

*All other solutions in Tables 1-3 contained 0.1M KF.

Table 2. Reaction Characteristics of Dissolver Solutions initially at Ambient Pressure

\begin{tabular}{|c|c|c|c|c|c|c|c|}
\hline $\mathrm{HNO}_{3}$ & HAN & Iron & Trxn & $\Delta \mathrm{T}$ & $\Delta \mathrm{P}$ & $\Delta \mathrm{t}$ & Comments \\
\hline $\mathrm{M}$ & $\mathrm{M}$ & $\mathrm{ppm}$ & ${ }^{\circ} \mathrm{C}$ & ${ }^{\circ} \mathrm{C}$ & $\mathrm{psi}$ & $\mathrm{sec}$ & \\
\hline & & & & & & & \\
\hline 2 & 0.6 & 0 & $109-110$ & 8 & 11 & 2.03 & Rxn. after boiling \\
\hline 2 & 0.6 & 1000 & $108-109$ & 7 & 10 & 1.98 & Rxn. after boiling \\
\hline & & & & & & & \\
\hline 3 & 0.6 & 0 & 101 & 15 & 14 & 2.3 & \\
\hline 3 & 0.9 & 0 & 101 & 16 & 14 & 2.14 & \\
\hline 3 & 0.9 & 1000 & 105 & 12 & 15 & 1.59 & \\
\hline
\end{tabular}

For the $\mathrm{HNO}_{3} / \mathrm{HAN} / \mathrm{KF}$ solution with iron, as shown in Table 3, the reaction initiation temperature ranged from 105 to $120.5 \mathrm{C}$, which is about $10^{\circ} \mathrm{C}$ lower than the range for the same solution in the absence of iron. At ambient pressure with iron, the typical dissolver solution behaves the same as without iron - a period of vaporization followed by a reaction at $108-109^{\circ} \mathrm{C}$. Thus, the presence of iron does not preclude use of the proposed HAN flowsheet, for which the planned temperature is $50-60^{\circ} \mathrm{C}$. 
Table 3. Reaction Characteristics of Dissolver Solutions with 1000 ppm Iron.

\begin{tabular}{|c|c|c|c|c|c|c|c|}
\hline $\mathrm{HNO}_{3}$ & $\mathrm{HAN}$ & Po & $\operatorname{Trxn}$ & $\Delta \mathrm{T}$ & $\Delta \mathrm{P}$ & $\Delta \mathrm{t}$ & Comments \\
\hline $\mathrm{M}$ & $\mathrm{M}$ & $\mathrm{psig}$ & ${ }^{\circ} \mathrm{C}$ & ${ }^{\circ} \mathrm{C}$ & $\mathrm{psi}$ & $\mathrm{sec}$ & \\
\hline & & & & & & & \\
\hline 2 & 0.6 & 300 & 105 & 25 & 6.4 & 1.54 & \\
\hline 2 & 0.6 & 300 & 112 & 23.5 & 4.7 & 1.04 & \\
\hline 2 & 0.6 & 50 & 121 & 17 & 16 & 0.82 & \\
\hline 2 & 0.6 & 50 & 118 & 18 & 15 & 0.99 & \\
\hline 2 & 0.6 & 30 & 112 & 17 & 13 & 1.37 & \\
\hline 2 & 0.6 & 30 & & & 16 & 0.99 & \\
\hline & & & & & & & \\
\hline 2 & 0.6 & 0 & $108-109$ & 7 & 10 & 1.98 & Rxn. after boiling $^{-6}$ \\
\hline & & & & & & & \\
\hline 3 & 0.6 & 300 & 98 & 25 & 4.8 & 0.60 & \\
\hline 3 & 0.9 & 300 & 91 & 39 & 2.7 & 1.94 & \\
\hline 3 & 0.9 & 0 & 105 & 12 & 15 & 1.59 & Aged solution $^{\dagger}$ \\
\hline
\end{tabular}

${ }^{\dagger}$ HAN/HNO3/KF solution made 46 days before test. Iron added 44 days before test.

The RSST calculates the heating rate, dT/dt, throughout a run. This can be called the selfheating rate, since the programmed heating rate is known. Figure 3 shows an example of heating rate versus time for samples with a $1^{\circ} \mathrm{C} / \mathrm{min}$ programmed rate. Individual runs were selected as representative, but do not show the range of reaction initiation temperatures observed in this study. In Figure 3, the "Typical" and "Concentrated" terms refer to the same concentrations as in Figure 2.

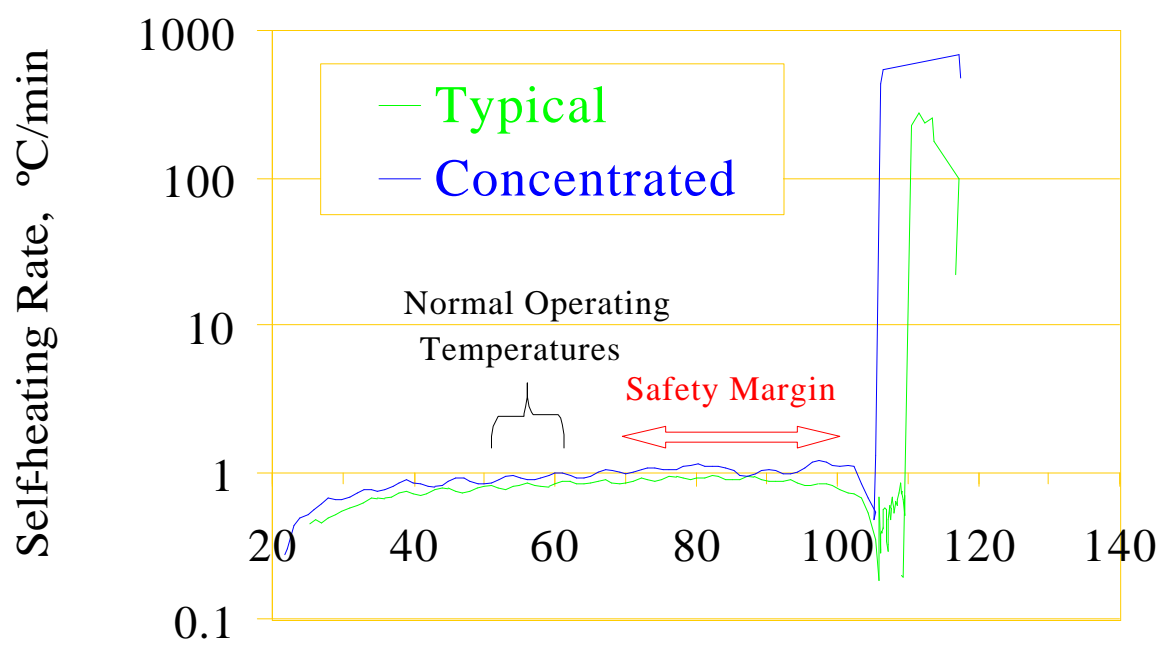

Temperature $\left({ }^{\circ} \mathrm{C}\right)$

Figure 3. Comparison of upset conditions to normal operating temperatures. 
WSRC-TR-2004-00342

\section{Conclusions}

The results of this study lead to the following conclusions.

1. Increasing the nitric acid concentration decreased the runaway reaction initiation temperature.

2. Increasing the HAN concentration increased reaction intensity.

3. Ambient pressure experiments demonstrated excessive boiling was required to achieve runaway reaction with typical flowsheet conditions.

4. Increasing fluoride to $0.2 \mathrm{M}$ had no effect on reaction initiation temperature.

5. The presence of iron $(1000 \mathrm{ppm})$ reduced the reaction initiation temperature $5-10^{\circ} \mathrm{C}$.

6. A significant safety margin exists between normal operating conditions for the $2 \mathrm{M} \mathrm{HNO}_{3}$ / 0.6M HAN / 0.1M KF flowsheet and upset conditions which lead to a runaway reaction.

\section{Acknowledgements}

The authors thank the Strategic R\&D Program at Savannah River Site for funding to perform this work and the Mixed Oxide Fuel Fabrication Project for funding to complete this report. We also thank Bill Crooks for technical assistance in using the RSST.

1 D.G. Karraker, Delta-Plutonium Processing - A HAN Process (U), WSRC-TR-90-251, Westinghouse Savannah River Co., Aiken, SC (June 1990).

2 D.G. Harlow, R.E. Felt, S. Agnew, G.S. Barney, J.M. McKibben, R. Garber, M. Lewis, Technical Report on Hydroxylamine Nitrate, DOE/EH-0555, U.S. Dept. of Energy, Feb. 1998.

${ }_{3}^{3}$ Pembridge, J.R., and G. Stedman, "Kinetics, Mechanisms, and Stoichiometry of the Oxidation of Hydroxylamine in Nitric Acid," Chemical Society Journal, Dalton, 1657, 1979. 